\title{
„Poległ wśród boju nauczycielskiego" Wspomnienia pośmiertne na łamach czasopisma „Szkoła" jako źródło do historii nauczycielstwa galicyjskiego
}

Wartość nekrologów dla badań biograficznych w nauce historycznej jest niekwestionowana. Jednakże dziewiętnastowieczna prasa codzienna i czasopisma popularne, odnotowując zgony różnych osób, skupiały się głównie na postaciach znaczących dla świata, narodu, tudzież danego regionu. Rzadko kiedy informowano o śmierci nauczycieli, chyba że były to postacie zasłużone czy to na polu naukowym, czy narodowym. Bynajmniej odejście nauczyciela szkół ludowych „nie cieszyło” się zainteresowaniem redakcji gazet. Lwowska „Szkoła” (18681939), będąca „czasopismem poświęconym sprawom szkół ludowych”, nie tylko odgrywała rolę forum wymiany myśli pedagogicznej oraz informacji z dziedziny oświaty, lecz także była swoistą kroniką szkolnictwa zaboru austriackiego - zarówno w dużych miastach, jak i wioskach galicyjskich¹. Dlatego też - obok

* Dr, Zakład Historii Polski Nowoczesnej, Instytut Historii, Wydział Historyczny, Uniwersytet Jagielloński, ul. Gołębia 13, 31-007 Kraków.

${ }^{1} \mathrm{Na}$ temat Iwowskiej „Szkoły” powstały zaledwie dwa artykuły: W. B o b r o w s k a-N o w a k, Problemy pedagogiczne na łamach „Szkoły”, „Przegląd Historyczno-Oświatowy” 1971, nr 2, s. $261-$ 277; A. Ś w i ą t e k, Problem patriotycznego wychowania ludu na łamach Iwowskiej "Szkoły” w czasach autonomii galicyjskiej, Czasopiśmiennictwo XIX i początków XX wieku jako źródło do historii edukacji, red. I. Michalska, G. Michalski, Łódź 2010, s. 169-184. O czasopiśmie wzmiankowano ponadto [w:] J. C i e m broniewi c z, Czasopisma pedagogiczne polskie, „Przegląd Pedagogiczny” 1903, nr 24, s. 292; H. R o wi d, Polskie czasopiśmiennictwo pedagogiczne, „Ruch Pedagogiczny” 1919, nr 9-10, s. 193-194; A. M o I a k, Z dziejów polskiej prasy pedagogicznej, „Nowa Szkoła” 1961, nr 10, s. 40; S. M oż ḋ̇e ń, J. M u s i ał, Bibliografia polskich czasopism pedagogicznych (do 1979 r.), Kielce 1981, s. XI, 191-192; S. M o ż d ż e ń, Czasopisma pedagogiczne w Galicji. Stan i potrzeby badań, [w:] Z dziejów oświaty w Galicji. Materiały z sesji naukowej zorganizowanej w Łańcucie w dniach 23-25 października 1986 roku na temat: „Stan i potrzeby badań nad dziejami oświaty w Galicji”, red. A. Meissner, Rzeszów 1989, s. 66; J. J a r o w i e c k i, Czasopisma pedagogiczne w Polsce, [w:] Encyklopedia pedagogiczna, red. W. Pomykało, Warszawa 1993, s. 81-82; J. J a r o w i e c k i, Czasopisma pedagogiczne w Polsce. Historia i teraźniejszość, [w:] t e n ż e, Studia nad prasą polską XIX 
artykułów pedagogicznych - na jej łamach znalazło się też miejsce na wiadomości oświatowe, wśród których nie zabrakło nekrologów. Informowano o odejściu znanych pedagogów, profesorów uniwersyteckich, naukowców pochodzących z innych regionów Polski, przebywających na emigracji oraz w państwach zaborczych. Wspominano dyrektorów szkół, ale również zwyczajnych, szeregowych nauczycieli.

Nekrologi pojawiały się na łamach pisma w kilku miejscach. W przypadku, gdy umierała osoba powszechnie znana, członek redakcji „Szkoły” lub osoba szczególnie zasłużona na polu oświaty galicyjskiej, wówczas poświęcano zmarłemu pierwszą stronę danego numeru. Prócz przedstawienia życiorysu i wyliczenia zasług, niejednokrotnie zamieszczano też podobiznę zmarłego. Tak było, gdy odchodził np. Zygmunt Sawczyński, znany działacz oświatowy i zarazem jeden z autorów „Szkoły”. W przypadku postaci znanych umieszczano czarną ramkę na dalszych stronach danego numeru, którą wypełniała informacja o śmierci, a następnie przywoływano krótki życiorys postaci. Najczęściej jednak nekrologi publikowane były w specjalnie wyodrębnionej rubryce zatytułowanej „Wspomnienia pośmiertne” albo zamieszczano je w działach z bieżącymi informacjami („Wiadomości potoczne z dziedziny szkolnictwa”; „Wiadomości bieżące”; „Rozmaitości”; „Rozmaitości krajowe i zagraniczne”). Nie były to w tych przypadkach obszerne nekrologi, niemniej jednak mimo to stanowią istotne źródło, zwłaszcza w przypadku osób nieznanych literaturze przedmiotu.

Nekrologi publikowane na łamach „Szkoły” nie różnią się szczególnie od drukowanych w innych czasopismach wydawanych w XIX w. W związku z niniejszym ich formę można uznać za klasyczną. Jacek Kolbuszewski, badając nekrolog jako formę literacką, dokonał rozbioru tego „gatunku” na kilka części. Zazwyczaj nekrolog rozpoczyna się od formuły otwarcia - „emocjonalnej preambuły". Czytamy wówczas, że szkoła, rodzina albo środowisko pedagogiczne zawiadamiają o śmierci danej osoby, dodając przy tym zapis - „z głębokim żalem” itp. Nie zawsze jednak w przypadku szkoły emocjonalna preambuła ma miejsce, często nekrolog przyjmuje formę zwyczajnego komunikatu, stwierdzającego fakty i podającego je gronu odbiorców. W drugiej części następuje powiadomienie o śmierci, a więc stwierdzenie faktów i okoliczności z nią związanych. Zazwyczaj podawane są informacje dotyczące dnia i miejsca zgonu. W tym miejscu pojawia się możliwość omówienia zasług i życiorysu zmarłego, co jest szczególnie interesujące źródłowo dla badaczy dziejów szkolnictwa ze względu na bogactwo treści odsłaniających się w tej właśnie części każdego nekrologu. Klasyczne nekrologi, publikowane na łamach dzienników, zawierały też informacje o miejscu i dacie pogrzebu, jednak w przypadku „Szkoły” tego typu informacje pojawiały się

i XX wieku, t. 1, Kraków 1997, s. 10-11; J. J a r o w i e c k i, Prasa Iwowska w dobie popowstaniowej, [w:] tamże, s. 41; J. J a r o w i e c k i, Prasa Iwowska 1864-1918. Bibliografia, Kraków 2002, s. 85; t e n ż e, Dzieje prasy polskiej we Lwowie do 1945 roku, Kraków-Wrocław 2008, s. 154-155. Nie podejmowano się jednak analizy zawartych na łamach pisma nekrologów.

2 „Szkoła” 1893, s. 253.

3 J. K o l b u s z e w s k i, Z głębokim żalem... O współczesnej nekrologii, Wrocław 1997, s. 71-77. 
znacznie rzadziej. Wynikało to przede wszystkim z faktu, że „Szkoła” przez długi czas była tygodnikiem, stąd droga, którą dany numer przebywał od wydawcy do odbiorcy była bardzo długa. Dlatego też publikowanie „zaproszeń” na pogrzeby byłoby bezcelowe, zawsze bowiem byłyby spóźnione.

Ostatnia część nekrologu mówi zazwyczaj o jego nadawcy. W większości przypadków w „Szkole” bezpośrednim nadawcą i autorem nekrologów była co prawda redakcja pisma, ale niejednokrotnie zdradzano informacje, kto konkretnie zawiadomił pismo o śmierci danej osoby. Często jest mowa o kolegach ze szkoły, rodzinie czy - generalnie - społeczności szkolnej.

Są to elementy, które przewijają się przez większość nekrologów i wspomnień, które nie były jednak pisane według odgórnie ustalonego szablonu. Stąd różnorodność prezentowanych treści.

Warto zwrócić uwagę, że każda część nekrologów jest przydatna źródłowo dla różnych dziedzin historii. Najbardziej interesująca pozostaje część poświęcona informacjom biograficznym, zawiera bowiem podstawowe fakty z życia zmarłego, ujawnia też opinię żyjących o nim i jego zasługach. Nie można patrzeć na te informacje bezkrytycznie, zwłaszcza, że w myśl zasady, iż „o zmarłych mówi się dobrze albo wcale", nie rozpisywano się o wadach, lecz o przymiotach odchodzących. Daleko zatem w tym przypadku do obiektywizmu, ale właśnie ta „wypaczona" (co zrozumiałe w tym przypadku) i skrócona wersja życiorysu zmarłego mówi o tym, co było doceniane przez redakcję, a więc szerzej - galicyjskie środowisko pedagogiczne - w jego pracy oświatowej.

Redakcja zwracała szczególną uwagę na śmierć osób zasłużonych, czy to dla polskiej kultury i oświaty, czy też w dziedzinie pedagogiki generalnie. Pojawiała się zatem okazja do przedstawienia nauczycielom dorobku zagranicznych pedagogów tudzież znanych postaci życia kulturalno-oświatowego w Europie w tym czasie. Przykładowo, wśród nekrologów z lat siedemdziesiątych XIX w. odnajdujemy takie osobistości, dziś już nieco zapomniane, jak: szkocki geograf i odkrywca Alexander Keith Johnston ${ }^{4}$; niemiecki filozof Ludwik Feuerbach ${ }^{5}$; niemiecki chemik Justus Liebig; ; niemieccy pedagodzy K. E. Bock ${ }^{7}$ i August Lüben ${ }^{8}$. Przypominano też osoby, które w jakiś sposób zasłużyły się dla sprawy polskiej, stąd nie zapomniano odnotować zgonu niemieckiego historyka Fryderyka Raumera ${ }^{9}$, przychylnego Polakom, a także o. Augustyna Theinera ${ }^{10}$, archiwisty watykańskiego i wydawcy źródeł watykańskich do historii Polski.

W przypadku zmarłych Polaków, kryterium decydującym podczas selekcji stawał się najczęściej fakt zaangażowania na polu narodowym i związek z ogólnie pojętą problematyką oświaty, choć i to nie było zasadą. Przypominano zatem czytelnikom zasłużonych ludzi nauki, historyków, pisarzy, polityków, działaczy

\footnotetext{
4 „Szkoła” 1871, t. 8, nr 33, s. 264.

5 „Szkoła” 1872, t. 9, nr 42, s. 336.

6 „Szkoła” 1873, t. 10, nr 18, s. 142.

7 „Szkoła” 1874, t. 11, nr 12, s. 105.

8 „Szkoła” 1873, t. 10, nr 47, s. 477

9 „Szkoła” 1874, t. 11, nr 26, s. 307.

10 Tamże, nr 35, s. 321.
} 
społecznych. Nie zabrakło w czasopiśmie adnotacji o uczestnikach polskich powstań narodowych czy działaczach emigracyjnych.

Najczęściej jednak bohaterami wspomnień pośmiertnych, publikowanych na łamach „Szkoły”, byli zwyczajni nauczyciele z różnych szczebli oświaty, począwszy od pracowników szkół ludowych, a skończywszy na profesorach Uniwersytetu Jagiellońskiego i Lwowskiego. O ile postacie związane z obu wszechnicami są raczej znane i zachowało się wiele źródeł na ich temat, o tyle w przypadku nauczycieli szkół ludowych nekrolog zamieszczony w „Szkole” może być kluczowym źródłem do opracowania biogramu zmarłego. Informacje biograficzne zawarte w nekrologach tworzą obraz galicyjskiego nauczyciela na wsi.

W źródłach innego typu raczej nie znajdziemy tak obszernego życiorysu zmarłego w Hujczu Eliasza Dackowa, jak zamieszczony we wspomnieniu pośmiertnym w „Szkole”. Czytamy bowiem w jego nekrologu nie tylko o wykształceniu tego chłopskiego nauczyciela i kolejnych szkołach, w których uczył, lecz także dowiadujemy się szerzej o jego aktywności społecznej (prowadzenie biblioteczki, prezentacja upraw w ogrodzie, nauczanie pieśni narodowych i religijnych, działalność w zarządzie Towarzystwa Pedagogicznego w Radziechowie itd. $)^{11}$.

Warto wspomnieć, że „Szkoła”, będąca w założeniu organem prasowym Towarzystwa Pedagogicznego, odzwierciedlała politykę tej instytucji, a pośrednio - nastroje panujące w krajowej oświacie. Z czasem, gdy zaostrzał się spór polsko-ruski o język wykładowy w szkołach, znalazło to odzwierciedlenie także w „Szkole”, co możemy analizować m.in. na podstawie tekstów publikowanych na łamach „Szkoły”12, lecz także w oparciu o zamieszczane w czasopiśmie wspomnienia pośmiertne. Do pewnego czasu, a konkretnie do zaostrzenia się konfliktu polsko-ruskiego/ukraińskiego na początku XX w., wspominanie o ruskich nauczycielach było czymś całkowicie naturalnym i niebudzącym zdziwienia, wszak część autorów czy redaktorów było etnicznymi Rusinami (np. Izydor Szaraniewicz, Zygmunt Sawczyński), dlatego też nie dziwiło wspominanie zmarłych nauczycieli narodowości ruskiej. Przykładem może być nekrolog: nauczyciela grecko-katolickiej szkoły we Lwowie Tytusa Dylińskiego, będącego zarazem członkiem Towarzystwa Pedagogicznego ${ }^{13}$. Nie zawsze jednak pisano, że dany nauczyciel był Rusinem, czasem wystarczyło typowe dla ludności ruskiej nazwisko (np. Bazyli Prokopowicz z Halicza ${ }^{14}$, Tymoteusz Rud' z Czerniatynia ${ }^{15}$, Aleksy Bublik ${ }^{16}$, Teodozy Floryański ${ }^{17}$, Bazyli Dmuchowski ${ }^{18} \mathrm{i}$ in.).

O tym, że do początków XX w. nie było jeszcze wrogości między obu narodowościami świadczą niektóre relacje z pogrzebów nauczycieli. Przykładowo na

\footnotetext{
11 „Szkoła” 1879, t. 16, nr 37, s. 304-305.

12 Szerzej czytaj: A. Ś w i ą t e k, Problem patriotycznego wychowania..., s. 180-183.

13 „Szkoła” 1873, t. 10, nr 49, s. 499.

14 „Szkoła” 1878, t. 15, nr 43, s. 357.

15 Tamże, nr 24, s. 191.

16 „Szkoła” 1882, t. 19, nr 18, s. 142.

17 „Szkoła” 1885, t. 22, nr 7, s. 54.

18 „Szkoła” 1897, t. 34, nr 46, s. 508.
} 
pogrzebie Jana Koczerkiewicza, zmarłego w Mistycach w powiecie mościckim, jego kolega, nauczyciel W. Krępowski, przemawiał do zgromadzonych po rusku, dziękował odprawiającemu nabożeństwo parochowi, a na koniec odśpiewano na cmentarzu Wicznaja pamiat ${ }^{19}$. Podobnie w pogrzebie Aleksandra Petryka, nauczyciela w Tuligłowach, uczestniczyło aż siedmiu duchownych, a mowę pogrzebową wygłosił greckokatolicki proboszcz z Siedlisk, ks. Kruszyński². O zgodnym współżyciu obu narodowości świadczy też fakt, iż nad ciałami nauczycieli niejednokrotnie pochylali się kapłani obu obrządków, wspólnie sprawując nabożeństwa. Tak było m.in. na pogrzebie Edmunda Porzyckiego, nauczyciela w Berlinie, w powiecie brodzkim ${ }^{21}$.

W „Szkole” chętnie wspominano osoby, które angażowały się na rzecz rozwoju szkolnictwa. W kontekście ruskim warto przywołać wspomnienie pośmiertne greckokatolickiego księdza Aleksego Bublika ze Szczerca, który, jak pisano, „gdzie sprawa słuszna i dobro ogólne miała na celu, popierał ją chętnie bez względu na narodowość i wyznanie"22. Zresztą pisano nie tylko o Polakach czy Rusinach, lecz także o wyróżniających się nauczycielach żydowskich, jednak było to zjawisko o wiele rzadsze. W 1883 r. zamieszczono np. wspomnienie pośmiertne Marcina Marbacha, nauczyciela izraelickiej szkoły ludowej w Brodach, który za swoją pracę został nawet odznaczony przez cesarza srebrnym krzyżem z koroną. Publicyści „Szkoły” pisali, że „wieść o śmierci ś.p. Marbacha wzbudziła żywe współczucie we wszystkich warstwach społeczeństwa naszego bez różnicy wyznania, a wyrazem tych uczuć były liczne tłumy publiczności przy pochodzie pogrzebowym"23. W zdecydowanej większości mamy jednak do czynienia z nekrologami polskich nauczycieli w galicyjskich szkołach.

O śmierci nauczycieli „Szkołę” najczęściej informowali ich znajomi (koledzy z pracy) lub rodzina, niekiedy sama redakcja czasopisma wychodziła z inicjatywą ogłoszenia smutnej wiadomości na swych łamach. Fakt autorstwa nekrologów jest szczególnie interesujący ze względu na więzi funkcjonujące w środowisku pedagogów w analizowanej epoce. Emocjonalny stosunek piszących do zmarłych nie pozwalał na obiektywne przedstawienie postaci, lecz nekrologi dawały możliwość bliższego poznania losu zmarłych nauczycieli. Przykładowo, nekrolog Edwarda Gołębiowskiego, zaledwie 33-letniego nauczyciela historii i geografii w gimnazjum tarnowskim, napisał jego własny nauczyciel, a zarazem wspomniany już działacz oświatowy, Zygmunt Sawczyński. Nie tylko opisał Gołębiowskiego bez wad, lecz także nakreślił jego życiorys, podkreślając, że wszelkie jego działania z przeszłości niejako zapowiadały, jakim wybitnym nauczycielem będzie. Tekst nacechowany patosem miał honorować zmarłego, ale przede wszystkim - zachęcić czytelników (środowisko nauczycielskie w Galicji) do brania z niego przykładu:

\footnotetext{
19 „Szkoła” 1881, t. 18, nr 51, s. 415.

20 "Szkoła” 1882, t. 19, nr 27, s. 214.

21 Tamże, nr 49, s. 391.

22 Tamże, nr 18, s. 142.

23 „Szkoła” 1883, t. 20, nr 44, s. 353.
} 
Ciągła sumienna około własnego kształcenia się praca, gorliwe nawet pomimo nadwerężonego w ostatnich latach zdrowia pełnienie obowiązków, praca dla dobra szkoły nawet na łożu boleści [...], żywe przywiązanie do młodzieży, jako przyszłości kraju, który kochał całą siłą młodej szlachetnej duszy z głęboką wiarą w sprawiedliwość Bożą - to cnoty publiczne [... $]^{24}$.

Nauczyciel w szkołach ludowych miał być wzorem cnót niejako z założenia. Jak ustalił w swych badaniach Andrzej Meissner, władze szkolne w urzędowych wydawnictwach poświęcały sporo miejsca określeniu ideału nauczyciela. Wskazywano szereg cech natury moralnej, intelektualnej i emocjonalnej, a także religijność ${ }^{25}$. Do tej dyskusji w wielu artykułach włączała się także „Szkoła”. Warto wymienić choćby artykuł E. Petryki, zatytułowany Jakie przymioty powinien posiadać dobry nauczyciel? Odpowiadając na tytułowe pytanie, wskazywano: religijność, moralność, sprawiedliwość oraz miłość do narodu, dzieci, Boga i ojczyzny. Bez tej miłości - według autora wspomnianego artykułu - nie można być wychowawcą ${ }^{26}$.

Tego typu wykładnia była wszechobecna na łamach „Szkoły”, dlatego też nic dziwnego, że cel moralno-dydaktyczny towarzyszył także nekrologom i wspomnieniom pośmiertnym. Oddawano hołd zmarłemu, ale przede wszystkim próbowano zwrócić uwagę na zasługi nauczycieli nie tyle na polu nauczycielskim, ile - szerzej - na płaszczyźnie społecznej, ogólnonarodowej. Wspominano przy tym zmarłych nauczycieli z prawdziwym namaszczeniem, hołdując ich cnotom i mozolnej pracy organicznej w dziedzinie szkolnictwa.

Gdy zmarł Stefan Borzemski, zaledwie zastępca nauczyciela w gimnazjum im. Franciszka Józefa we Lwowie, pisano o jego śmierci w stylistyce niemal martyrologicznej: „[...] poległ wśród boju nauczycielskiego, wśród pełnienia swego zawodu. Cześć jego pamięci! Pokój jego popiołom!"27. Chociaż nauczyciele nie ginęli na skutek ran, to język wspomnień pośmiertnych zastąpił tego typu cierpienia problemami zdrowotnymi wynikłymi $z$ wieloletniej, żmudnej pracy w szkole. Przykładowo o Maksymilianie Baleju, nauczycielu szkoły w Cebrowie w powiecie tarnopolskim, pisano, że „był prawdziwą ozdobą nauczycielstwa tutejszego i należał do rzędu tych pedagogów, którzy z zamiłowania do swego zawodu tracą swe zdrowie w izbie szkolnej dla dobra pokoleń" ${ }^{28}$. Z kolei Franciszkę Sokulską z Brodów wspominano w stylistyce wręcz militarnej: „umarła, jak dobry żołnierz, na polu walki, albowiem jeszcze 4 dni przed śmiercią uczyła dzieci w szkółce wiejskiej, w której pracowała [...]"29. Śmierć nauczycieli czy też uszczerbek na ich zdrowiu urastały zatem do rangi symbolu i za sprawą autorów wspomnień pośmiertnych ulegały swoistej sakralizacji.

24 Z. S a w c z y ń s k i, Edward Gołębiowski. Wspomnienie pośmiertne, „Szkoła” 1868, t. 1, nr 2, s. $132-133$.

${ }^{25}$ A. M e i s s n e r, Spór o duszę polskiego nauczyciela. Społeczeństwo galicyjskie wobec problemów kształcenia nauczycieli, Rzeszów 1999, s. 171.

${ }^{26}$ E. P e tr y k a, Jakie przymioty powinien posiadać dobry nauczyciel?, „Szkoła” 1870, nr 18, s. $273-278 ;$ nr 19 , s. 289-293.

27 „Szkoła” 1871, t. 7-8, nr 32, s. 256.

28 „Szkoła” 1874, t. 11, nr 32, s. 292.

29 "Szkoła” 1883, t. 20, nr 17, s. 134. 
Podkreślano misyjny charakter pracy zmarłych nauczycieli, wymieniając ich zalety i konkretne czyny, niejednokrotnie podkreślając apostolski charakter zmagań w dziedzinie oświaty. Przykładem niech będzie wspomnienie o nauczycielu szkoły ludowej w Porębie, Józefie Bernadzikiewiczu:

Śmiercią tego starego druha utraciła ojczyzna jednego z niewielu apostołów, co sieją obficie z miłością i nadzieją, aby przyszłość miała co zbierać. Całe też pasmo życia śp. nieboszczyka było żywym przykładem cnót chrześcijańskich: cichej pracy, miłości gotowej nawet do poświęceń dla bliźnich. Nie brakło atoli i ciężkich doświadczeń w życiu śp. Bernadzikiewicza - wycierpiał on wiele; lecz dźwigał krzyż wszędzie i bez szemrania, aby tylko spełnić godnie i uczciwie misją przyjętą ${ }^{30}$.

Faktycznie, praca wielu nauczycieli miała charakter prawdziwie zaangażowanej służby społeczeństwu, co niekiedy spotykało się z wyrazami uznania ze strony żyjących. Gdy odszedł Feliks Szumlański, znany we Lwowie nauczyciel śpiewu i zarazem autor wielu pieśni i kolęd, wspomniano o tym, że „swój, dosyć znaczny majątek zapisał zmarły na stypendia i wsparcie dla ubogiej młodzieży"31. Dużym uznaniem cieszył się również emerytowany dyrektor szkół ludowych w Jaśle, Józef Koncki, który „umiał sobie zaskarbić powszechne zaufanie i miłość młodzieży", za co otrzymał honorowe obywatelstwo w swoim miasteczku².

Tego typu przypadki należały jednak do wyjątków. Chociaż nauczyciele szkół ludowych cieszyli się bardzo często uznaniem ze strony swoich podopiecznych tudzież środowiska pedagogicznego, to jednak nie mieli lekkiego życia. Mimo ukończenia seminarium nauczycielskiego albo gimnazjum nie zasilali lokalnej „elity”, którą tworzyły osobistości z kręgów ziemiańskich oraz inteligenckich. Zresztą, jak pisze Jadwiga Hoff, w XIX w. nauczycielstwa szkół ludowych wcale nie zaliczano do inteligencji, tak jak to miało miejsce w przypadku nauczycieli w gimnazjach miejskich ${ }^{33}$. Niejednokrotnie zatem nauczyciel pełnił swą misję, żyjąc na wsi nie inaczej, aniżeli wychowywani przez niego włościanie.

Nekrologi publikowane w „Szkole” często odsłaniają fakt, że wielu nauczycieli świadomie się pisało na warunki, w których musieli żyć i pracować za niewielkie pieniądze. Mowa tu o nauczycielach, którzy pracowali z pasją. Warto zacytować obszerniejszy fragment nekrologu Józefa Karpińskiego, nauczyciela ludowego w Święcanach. Jego poświęcenie i zaangażowanie, a jednocześnie wierność podjętej misji niesienia kaganka oświaty nie pozostały niezauważone przez redakcję „Szkoły”:

Prawym charakterem, pracą i dobrocią serca zjednał sobie poważanie i szacunek we dworze, na plebani i między ludem. Zamiłowawszy się w tym zawodzie, poczuł, że obrał stan, w którym może być szczęśliwy. Przełożeni, poznawszy pracę i takt w postępowaniu jego, proponowali mu lepsze i zaszczytniejsze posady, lecz ś.p. Józef podziękował za nie, gdyż miał tę, dziś niestety tak rzadką zaletę, że wolał raczej różne niewygody a czasem i niedostatek cierpieć, aby tylko posad, którą uważał za gniazdo rodzinnie, nie zmieniać ${ }^{34}$.

\footnotetext{
30 „Szkoła” 1874, t. 11, nr 19, s. 164.

31 Tamże, nr 4, s. 31.

32 Tamże, nr 15, s. 130.

${ }^{33} \mathrm{~J}$. H o ff, Mieszkańcy małych miast Galicji Wschodniej w okresie autonomicznym, Rzeszów

34 „Szkoła” 1879, t. 16, nr 36, s. 296.
} 2005, s. 78. 
Nie zawsze za opisem osiągnięć życiowych stała jedynie chęć ukazania znaczenia wieloletniej pracy pedagogicznej, mającej służyć wychowywaniu przyszłych pokoleń. Wielu nauczycieli angażowało się także poza budynkiem szkoły, dokonując ważnych odkryć, stosując nowatorskie wówczas metody albo publikując swoje własne rozprawy i książki. Dotyczyło to jednak raczej nauczycieli szkół miejskich, zwłaszcza gimnazjów.

Niekiedy pomysłowość nauczycieli i wprowadzane do edukacji innowacje budziły niepokój policji. Informacji o czasach, jakby nie było - zaborczych, dostarcza wspomnienie pośmiertne nauczyciela gimnazjum Św. Jacka w Krakowie, Franciszka Szynglarskiego, który zgromadził w swej szkole różnego typu przyrządy do ćwiczeń i pokazywał ćwiczenia uczniom, przychodzącym przed lekcjami. „Szkoła” pisała o niezwykłym wówczas pomyśle nauczyciela. O tym, jaką to było nowością (rok 1865), można wnioskować na podstawie reakcji organów bezpieczeństwa publicznego, które w ćwiczeniach tych dopatrywały się zakłócenia spokoju publicznego. Ostatecznie Szynglarski musiał tłumaczyć się z podejmowanych działań swoim zwierzchnikom ${ }^{35}$.

Nekrologi i wspomnienia pośmiertne mogą służyć jako bardzo interesujące źródło do odtwarzania etapów kariery zawodowej galicyjskich nauczycieli, co w zestawieniu z Szematyzmami Królestwa Galicji i Lodomerii z Wielkim Księstwem Krakowskim pozwala na ściślejszą rekonstrukcję kariery zawodowej poszczególnych nauczycieli. Bardzo często wymieniano bowiem kolejne szkoły, w których dany nauczyciel pracował, oraz stanowiska, które piastował. Na przykład, gdy zmarł we Lwowie Andrzej Oskard, przywołując jego życiorys przypominano, że zaczął przygodę ze szkołę w gimnazjum tarnowskim, potem przeniósł się do gimnazjum św. Anny w Krakowie, następnie objął posadę dyrektora gimnazjum w Rzeszowie, żeby znów powrócić do Tarnowa, także jako dyrektor. W końcu zaś, mając tak duże doświadczenie w pracy nauczycielskiej i kierowniczej, został inspektorem krajowym w Galicji Zachodniej, a następnie przeniósł się do Lwowa, gdzie kontynuował nadzór nad szkołami średnimi, ale już w całej Galicji. Pod koniec życia objął posadę dyrektora Iwowskiego gimnazjum Franciszka Józefa $^{36}$. Tego typu życiorysów zawodowych nie brakuje w nekrologach publikowanych w „Szkole”.

Autorzy interesujących nas tekstów obecnych na łamach „Szkoły” z przejęciem opowiadają o sytuacji bytowej warstwy nauczycielskiej (zwłaszcza dotyczy to nauczycieli szkół ludowych). Zarobki w szkołach gimnazjalnych nie były bowiem wcale złe, a jeśli dany nauczyciel awansował w hierarchii szkolnej, to powodziło mu się całkiem dobrze, co wykazała w swych badaniach Henryka Kramarz $^{37}$. Tymczasem dochody nauczycieli w szkołach ludowych nie były wysokie

35 „Szkoła” 1875, t. 12, nr 37, s. 315.

36 „Szkoła” 1874, t. 11, nr 40, s. 368.

37 H. K r a m a r z, Nauczyciele gimnazjalni Galicji 1867-1914. Studium historyczno-socjologiczne, Kraków 1987, s. 167. 
i utrzymanie z nich rodziny, a nawet tylko siebie było nie lada wyzwaniem. W wielu tekstach przewija się wątek problemów finansowych nauczycieli. Nie był to zresztą problem wyłącznie galicyjski, dotykał wykonujących ten zawód także w innych zakątkach tej części Europy. Dowodem może być tragiczna historia pewnego emerytowanego nauczyciela w Nordhausen, który podciął sobie żyły, uprzednio podkładając świecę, aby jego ciało się spaliło. Jak pisano w „Szkole”: „Przyczyną tego była nędza, całe jego utrzymanie wynosiło bowiem rocznie 50 talarów"38. Emerytura nauczyciela w Galicji również nie była wysoka, choć na szczęście nikt nie popełniał z tego powodu samobójstwa. W 1883 r. wspominano Franciszkę Sokulską, emerytowaną dyrektorkę szkoły żeńskiej w Brodach, która po 52 latach pracy otrzymała emeryturę wysokości 260 złotych $^{39}$.

Ubóstwo doskwierało nie tylko nauczycielom, ale także ich rodzinom. Śmierć zarabiającego na utrzymanie całej rodziny nauczyciela stawiała jego najbliższych w niezwykle trudnej sytuacji materialnej. W takim położeniu znalazła się m.in. rodzina nauczyciela z Dobczyc, Feliksa Pankiewicza, który zostawił żonę bez żadnego majątku ${ }^{40}$. Niekiedy nauczyciele żyli w takim ubóstwie, że nie było za co zorganizować im pogrzebu. Tego typu przypadki były paradoksalnie „dobrą” okazją, aby „wykrzyczeć”, w jak ciężkiej sytuacji materialnej znajduje się galicyjskie grono pedagogiczne. Gdy zmarł nauczyciel szkół ludowych Mikołaj Hoszowski, na łamach „Szkoły” pisano:

[...] umarł w takiej nędzy, że trzeba było składkę zrobić na trumnę i pogrzeb, inaczej możeby był zwykłą metodą skarbową pochowany. Wspominamy o tej okoliczności dlatego, ponieważ niedostatek, dawający się w ogóle czuć u wszystkich na pewne stałe płace ograniczonych ludzi, dopieka najgorzej nauczycielom szkół ludowych ${ }^{41}$.

Podobna sytuacja miała miejsce, gdy odszedł Maurycy Januszewski z powiatu tarnopolskiego. Jego śmierć dramatycznie opisywano w „Szkole” nie tylko ze względu na rozstanie się nauczyciela z tym światem, lecz także z powodu troski o byt jego rodziny. Januszewski - jak pisano w czasopiśmie:

[...] nie mógł nawet mieć spokojnego konania, bo widok sześciorga dzieci nieopatrzonych, z których najstarsze liczy 13 lat, i widok biednej opuszczonej żony, która ostatnie skarby małżeńskie, obrączki ślubne, poświęciła dla ratowania ojca i męża, utrudniały śp. Maurycemu rozstanie się ze światem, wiedział bowiem dobrze, że nawet jego trupa nie będzie za co pochować. I tak było rzeczywiście ${ }^{42}$.

Relacjonowano dalej, że udało się zebrać pieniądze na pogrzeb, a rodzinę wspomagały osoby prywatne. Często jednak współpracownicy „Szkoły” sami podejmowali się wspomożenia nauczycielskich rodzin, zamieszczając prośby o składki na łamach pisma. Apelowali o solidarność całego środowiska pedagogicznego,

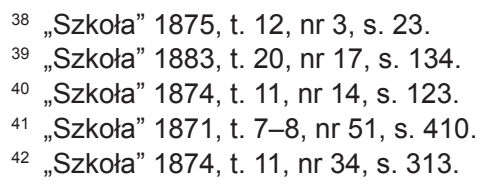


aby wesprzeć wdowy i sieroty po nauczycielach. W szczególnie ciężkiej sytuacji znalazła się m.in. rodzina Jana Węcka, nauczyciela ludowego z Borek Małych w powiecie tarnopolskim, który pozostawił siedmioro dzieci. Jego żona w rozpaczy zwróciła się o pomoc do „Szkoły”, a redakcja opublikowała apel do ogółu nauczycielstwa z prośbą o pomoc finansową ${ }^{43}$. Jak się okazało, spotkał się z pozytywną reakcją grona czytelniczego. Parę numerów później redakcja opublikowała krótką listę darczyńców oraz odnotowała uzbieraną sumę - 7,5 złotego reńskiego ${ }^{44}$. Kilka lat później w podobny sposób zbierano fundusze na pomoc dla wdowy po nauczycielu o inicjałach E.P. (prawdopodobnie mowa o zmarłym niewiele wcześniej Edmundzie Porzyckim). Istotny jest fakt, że odzew czytelników „Szkoły” doprowadził do zebrania przeszło 14 złotych reńskich, a później jeszcze nadesłano kolejne 2 złote reńskie, które przekazano kobiecie. Obdarowana w jednym z numerów skierowała oficjalne podziękowania do darczyńców ${ }^{45}$.

Nie tylko przypadkami ubogich nauczycieli i ich rodzin zajmowano się w „Szkole”. Interweniowano także w sprawie osób powszechnie znanych, zasłużonych dla kraju. Przykładowo, gdy zmarł Karol Szajnocha, w „Szkole” apelowano o składki, tłumacząc:

Byłoby wstydem dla społeczeństwa naszego, gdyby teraz mógł kto powiedzieć: oto dlaczego, iż życie Karola spłynęło na bezpośredniej służbie około sprawy powszechnej, widzi się obecnie osierocona rodzina jego zagrożoną niedostatkiem... ${ }^{46}$

Zwieńczeniem życia ludzkiego jest pogrzeb. Chociaż nie ma już zmarłego wśród żywych, to jednak jego życie oraz zasługi dla innych odbijają się w postawie rodziny, bliskich i społeczności czy nawet społeczeństwa, w którym żył. Badanie pogrzebów stwarza interesujące możliwości, bowiem informacje o tym, ile osób uczestniczyło w pogrzebie, przedstawiciele jakich organizacji brali w nim udział, duchowieństwo jakiego wyznania odprawiało nabożeństwo, jaka była treść przemówień podczas ostatniej drogi zmarłego pomagają dokonać rekonstrukcji obrazu nauczycielstwa galicyjskiego w XIX w. Jakże wiele mówią o zasługach Grzegorza Jaremy, c.k. inspektora szkół ludowych okręgu stanisławowskiego, krótki nekrolog i relacja z pogrzebu:

Pogrzeb odbył się 5 b. m. [XI 1874 r.] przy tak licznym udziale publiczności, jak już dawno tego nie pamiętają. Młódź szkolna, wszystkie c.k. władze, wojskowość, stowarzyszenie „Gwiazda” z swoim sztandarem itp. oddali ostatnią przysługę ogólnie lubionemu i poważanemu mężowi. Nad grobem przemówił krótko, lecz nader wymownie i stosownie do okoliczności pełnego zasług żywota nieboszczyka, profesor seminar[ium] naucz[ycielskiego], p. Baranowski ${ }^{47}$.

\footnotetext{
43 „Szkoła” 1875, t. 12, nr 38, s. 325-326; nr 44, s. 377.

44 Tamże, nr 47.

45 „Szkoła” 1882, nr 51, s. 407; 1883, t. 20, nr 4, s. 31; nr 10, s. 79.

46 B. K a l i c k i, Odezwa do ziomków, „Szkoła” 1868, t. 1, nr 2, s. 135.

47 „Szkoła” 1874, t. 11, nr 46, s. 434.
} 
Jak bardzo zasłużony był G. Jarema dla społeczności lokalnej, dlaczego w pogrzebie uczestniczyło wojsko i władze, co łączyło zmarłego ze stowarzyszeniem „Gwiazda” i dlaczego przemowę nad grobem wygłosił profesor Baranowski, a także kim był dla Jaremy? Odpowiedzi na te pytania pozwolą zrekonstruować życiorys wspominanego nauczyciela. Chociaż nekrolog nie zawiera odpowiedzi, to jednak bez zamieszczonych w nim informacji nie wiedzielibyśmy, że takie pytania trzeba zadać, badając historię tego nauczyciela.

Równie interesująca, wymagająca głębszej analizy jest wzmianka o śmierci Emilii Bolechowskiej, nauczycielki szkoły żeńskiej w Tarnopolu. Jej pogrzeb w 1875 r. zgromadził licznych uczestników, nabożeństwo zostało odprawione przez duchownych obu obrządków (rzymsko- i greckokatolickiego), w obecności nauczycieli i uczniów ${ }^{48}$.

Pogrzeb pełnił także funkcję integrującą w ramach społeczności, która żegnała zmarłego. Pochylając się nad trumną, można było docenić jego szkolne zmagania. Służyły temu m.in. kazania podczas nabożeństw i przemowy wygłaszane przez bliskich. Niekiedy mowy te relacjonowano we wspomnieniach pośmiertnych. $\mathrm{Na}$ ich podstawie jesteśmy w stanie wyobrazić sobie sam pogrzeb i odtworzyć emocje uczestników. Gdy zmarł Stanisław Sołtysek, nauczyciel szkoły w Zielonkach pod Krakowem, na jego pogrzebie zgromadziła się liczna publiczność oraz kilku kapłanów. Jeden z nich, niejaki ks. Szajkowski, w swej przemowie „oddał cześć zasługom zmarłego, a przytaczając ustępy z pisma św. i z pism pogańskich mędrców, podniósł zacność stanu nauczycielskiego i oddał mu cześć". Jak notowano dalej: „Przemowa ta, jak to spostrzec można było, zrobiła na słuchaczów włościańskich głębokie wrażenie"49. Ilekroć czytamy wspomnienia pośmiertne, w których wspomniano o pogrzebie, tylekroć dowiadujemy się o licznym udziale ludności, obecności kilku duchownych itp. Świadczy to dobitnie o roli, jaką spełniali nauczyciele ludowi w swoich niewielkich społecznościach.

Reasumując można stwierdzić, że Iwowska „Szkoła” stanowi dla współczesnego badacza oświaty galicyjskiej w epoce autonomicznej ogromny materiał. Wspomnienia pośmiertne nauczycieli dopełniają obraz nauczycielstwa galicyjskiego, kreślony w publikowanych w czasopiśmie artykułach pedagogicznych. Paradoksalnie, dzięki tym krótkim tekstom, niosącym smutną wieść o śmierci nauczycieli, oni sami ożywają - poznajemy ich dotychczasowe życie codzienne, ich bolączki, sytuację materialną, ich osiągnięcia oraz zasługi na polu wychowania młodszych pokoleń, a także dostrzegamy wszystkich tych, dla których ich odejście było stratą. Wprawdzie losy nauczycieli ludowych jesteśmy w stanie odtwarzać, wykorzystując m.in. wspomniane Szematyzmy..., ale tego typu źródła dostarczają jedynie suche fakty: kto, gdzie i kiedy nauczał. Tymczasem nekrologi, publikowane w wielkiej liczbie w Iwowskiej „Szkole” dostarczają szczegółów, pomocnych podczas poszukiwań biografistycznych. Wszak przez pół wieku, rok po

\footnotetext{
48 „Szkoła” 1875, t. 12, nr 31, s. 258.

49 „Szkoła” 1877, t. 14, nr 24, s. 239.
} 
roku, aż do odzyskania niepodległości przez Polskę, na łamach „Szkoły” zamieszczano kilkadziesiąt wspomnień pośmiertnych, nekrologów tudzież krótkich informacji o zgonach osób związanych z oświatą. 72-letni okres wydawania "Szkoły” dostarczył zatem badaczom szkolnictwa tysiące nekrologów, stanowiących obfity materiał biograficzny do opracowania życiorysów nauczycieli zaboru austriackiego. To niezwykłe źródło do badań nad życiem codziennym i problemami kadry pedagogicznej w Galicji. 